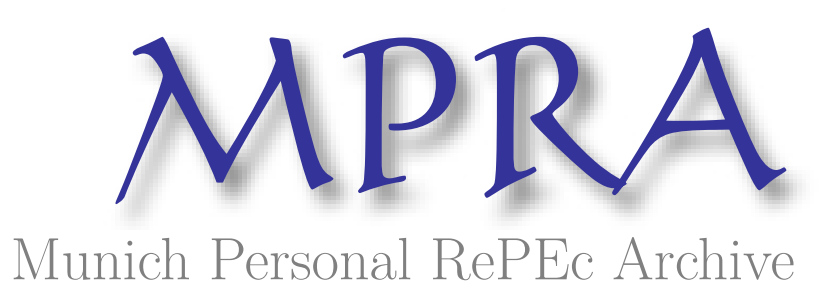

\title{
Financial regulation and bank supervision during a pandemic
}

Ozili, Peterson Kitakogelu

2021

Online at https://mpra.ub.uni-muenchen.de/105887/

MPRA Paper No. 105887, posted 08 Feb 2021 11:10 UTC 


\title{
Financial regulation and bank supervision during a pandemic
}

\author{
Peterson K. Ozili
}

\begin{abstract}
Pandemics lead to a sudden decline in the level of economic activities. Lending institutions reduce credit supply to businesses due to fears of rising bad debts during a pandemic. This paper highlights some approach to financial regulation and bank supervision during a pandemic such as the SARS and COVID-19 pandemic. The approach suggested in this paper are intended to be applicable to all types of pandemic since their effect on banks and financial institutions are relatively the same.
\end{abstract}

Keyword: Pandemic, COVID-19, coronavirus, SARS, bank regulation, financial institution, banks, bank supervision, financial regulation.

JEL Code: G21, G28.

February 2021 


\section{Introduction}

This paper highlights some approach to financial regulation and bank supervision during a pandemic.

The outbreak of Severe Acute Respiratory Syndrome (SARS) in 2003 and the more recent coronavirus COVID-19 pandemic in 2020 have one thing in common which is that they threatened short-term growth prospects in the global economy. The downward revision in global growth forecasts by the World Bank and the International Monetary Fund showed that the pandemic which is primarily a health problem - had spillover effects to many sectors of the economy (Ozili and Arun, 2020). During the COVID-19 pandemic, the downward revision in global growth forecast was caused majorly by nationwide lockdown restrictions in some countries and strict social distancing policy measures in other countries (Chudik et al, 2020; Ozili, 2020a; König and Winkler, 2020).

Apart from lockdowns, the other important channel through which pandemics affect the level of economic activities is through abnormal cuts in credit supply to the real sector by financial institutions and financial markets. Financial institutions often reduce lending to businesses during a pandemic, or lend at high interest rates to businesses in need of working capital during a pandemic due to rising credit risk concerns. During the 2020 COVID-19 pandemic, bank credit supply declined significantly (see Ari et al, 2020; Ozili and Arun, 2020; Jing, 2020, Ozili, 2020b). There are many studies on the impact of a pandemic on financial institutions and financial markets (e.g. Zhang et al, 2020; Topcu and Gulal, 2020; Ozili and Arun, 2020; Li et al, 2020). Only few studies examine how a pandemic affects financial regulation and bank supervision.

The discussion in this paper contribute to the emerging literature on the policy response of governments to a pandemic such as the coronavirus crisis. This article also contributes to studies that examine the effort of financial 
regulators in helping financial institutions to withstand the negative effects of the pandemic on their balance sheets.

The rest of the paper is structured in the following way. Section 2 presents the literature review. Section 3 highlights and discuss some approach to financial regulation. Section 4 highlights and discuss some approach to bank supervision. Section 5 concludes.

\section{Literature review}

Some studies examine the impact of a pandemic on a country's financial and economic system, and suggest some recommendations.

Fan (2003) highlight the channels through which the impact of the SARS pandemic was felt. Fan (2003) show that: (i) the SARS pandemic of 2003 affected economic growth by reducing demand which led to a significant reduction in private consumption spending as consumer confidence dramatically declined in many economies, (ii) the overall level of investment reduced due to heightened uncertainties and increased risks, (iii) foreign investment inflow was delayed or reduced in reaction to SARS, and (iv) government spending to mitigate the impact of SARs on the economy was limited.

During the coronavirus COVID-19 pandemic, Ozili and Arun (2020) show that the spread of the virus encouraged social distancing which led to the shutdown of financial markets, corporate offices, businesses and events. The exponential rate at which the virus was spreading, and the heightened uncertainty about how bad the situation could get, led to flight to safety in consumption and investment among consumers, investors and international trade partners. Ozili and Arun (2020) draw on real-world observations in assessing the restrictive measures, monetary policy measures, fiscal policy 
measures and the public health measures that were adopted during the period, and show that the increasing number of lockdown days, monetary policy decisions and international travel restrictions severely affected the level of economic activities as well as the closing, opening, lowest and highest stock price of major stock market indices.

Schularick et al (2020), in their analysis of the possible impact of COVID-19 using several scenarios, estimate a capital shortfall of up to 600 billion euro in European banks in a severe scenario, and a capital shortfall of around 143 billion euro in a moderate scenario. They then propose a precautionary recapitalization of European banks that would safeguard financial stability, and position the Eurozone for a quick recovery from the pandemic. Giese and Haldane (2020) compare and contrast the resilience of the financial system during the 2008 global financial crisis and 2020 COVID-19 pandemic. They show that banks are part of the solution for coping with a pandemic rather than part of the problem as was the case during the 2008 global financial crisis.

Li et al (2020) show that banks faced the largest increase in liquidity demands at the peak of the COVID-19 pandemic in March 2020. Firms drew funds on a massive scale from pre-existing credit lines in anticipation of cash flow and financial disruptions caused by the COVID-19 crisis. The increase in liquidity demands was concentrated at the largest banks who serve the largest firms. Also, the inflow of funds from both the Federal Reserve's liquidity injection programs and depositors, along with strong bank capital, explain why US banks were able to accommodate these liquidity demands during the COVID19 pandemic.

Demirguc-Kunt et al (2020) examine the role of financial sector policy announcements on the performance of bank stocks, and show that measures of liquidity support, borrower assistance and monetary easing reduced the 
adverse impact of the COVID-19 crisis on some banks not all banks. Meagher (2020), in his analysis of microfinance providers (MFPs), calls for an approach that is empathetic toward vulnerable clients, attuned to the specific risks of microfinance services, and open to communication and consultation with the industry. He suggests that regulators should enable MFPs to operate safely, provide relief to microfinance clients, make additional liquidity available to MFPs, defer non-critical supervisory processes, and restructure or liquidate troubled MFPs.

World Economic Forum (2020) suggests that policy-makers should ensure that the financial system remains capable of safely meeting the public's need for financial services through digital channels, and that regulators and central banks should continue to coordinate policy on a global level to help maintain financial stability while issuing clear and consistent policy guidance. Didier et al (2020) suggest ways to finance firms during the COVID-19 pandemic. They suggest that firms should hibernate their activities to the barest minimum by using the minimum cash necessary to withstand the pandemic while using credit to remain alive until the crisis subdues.

\section{Approach to financial regulation during a pandemic}

\subsection{Diversify the financial system}

There is need to diversify the financial system much early before a pandemic comes. Recently, financial institutions have become too similar to each other, and this can make financial crises more likely and frequent (Goodhart and Wagner, 2012). Investment banks now offer the same products and services that commercial banks offer (Goodhart and Wagner, 2012). Mortgage companies offer loans which banks offer, and banks also offer mortgage loans too. Large financial institutions now operate in the same global financial markets, undertake very similar activities, and are exposed to the same 
funding risks - and this has made their survival very intertwined and interconnected (Goodhart and Wagner, 2012).

A regulatory approach that would encourage greater diversity in the financial system to reduce the interconnectedness of large financial institutions is needed. Such regulatory approach should be introduced and adopted long before a pandemic begins, so that it can help to mitigate possible contagion risks that may arise from a pandemic. One idea to diversify the financial system is for policy makers to introduce many small financial institutions that specialize in specific activities. Such specialization can help to reduce the contribution of each financial system to systemic risk which may be amplified during a pandemic (Goodhart and Wagner, 2012).

\subsection{Maintain adequate liquidity in the financial system}

Financial regulation should focus on the ability of market makers to provide liquidity to the market during a pandemic. Heightened uncertainty in financial markets caused by a pandemic can lead to liquidity hoarding, and create a situation where fund managers are constantly seeking liquidity when the capacity of markets to provide liquidity has diminished significantly. This can lead to forced asset sales and may amplify adverse market dynamics.

Financial regulators should also be ready to provide emergency liquidity to the markets to reduce liquidity risk during a pandemic. Financial regulators, such as central banks, have two options to provide liquidity to the markets during a pandemic. They can either provide liquidity directly to non-banks, or they can purchase large quantities of illiquid assets in the market. This can help to stabilize the markets, address the issue of illiquidity, instill confidence and reduce systemic stress in financial markets. 


\subsection{Stimulate financial institutions to provide more credit}

Financial institutions are often reluctant to increase lending during a pandemic. To encourage financial institutions to increasing lending during a pandemic, financial regulators need to use several incentives to stimulate financial institutions to increase lending, such as: offering implicit guarantees to liquidity providers; providing capital relief to troubled financial institutions; lowering the interest rate at which financial institutions borrow from the central bank; providing differentiated financial support to distressed financial institutions; launch asset purchase programs to purchase illiquid assets from corporations; postponing counterparty debt repayment; release a large portion of cash reserve ratio to banks; and offering credit guarantees to lenders. These incentives can go a long way to encourage financial institutions to increase lending during a pandemic.

\subsection{Delay the recognition of significant increase in credit risk}

Financial regulators should allow financial institutions, especially banks, to formally delay the recognition of any significant increase in credit risk on their loan exposures. Banks should be allowed to take a long time to fully recognize rising nonperforming loans (NPLs) because if they recognize the actual level of NPLs during the pandemic, the reported NPLs could result in excess loan loss provisioning which may erode bank profit and affect bank stability in the short term. For this reason, it makes sense for regulators to allow banks to revise their NPL projections and delay the recognition of large NPLs in order to help them cope with the impact of an economic downturn caused by a pandemic. But this should not be an excuse to banks for failing to have in place strict loan deterioration monitoring and management strategies to identify credit risk at an early stage. Bank supervisors should ensure that banks proactively identify and engage with potentially distressed borrowers. 


\subsection{Lower the reference interest rate to boost economic activities}

A reference interest rate is an interest rate used as a benchmark to set other interest rates. In some developed countries, the reference rate is usually the London Inter Bank Offering Rate (LIBOR) or some other interbank rate. In many other countries, the reference rate is usually the central bank's lending rate. During a pandemic, a low interest rate by the central bank will mean cheaper federal funds for banks to borrow, and cheaper bank loans for businesses and households.

\subsection{Provide stimulus packages to the general economy}

Financial regulators should provide stimulus packages to the general economy. They can do this by, for example, reducing the amount of capital that banks need to set against risky lending during the pandemic so that banks can expand lending to businesses and households in such times. Two, financial regulators, especially central banks, can support large firms by offering them cash for their corporate debt. This can help large firms to keep paying wages to employees and pay their suppliers when they have serious cash flow problems. Three, they can provide short term funding as transfers to individuals and small and medium scale enterprises. This can help to support businesses and consumer confidence during the pandemic, improve the cash flow of businesses and households, reduce the cost of finance, and improve the availability of finance. 


\section{Approach to bank supervision during a pandemic}

\subsection{Adopt a flexible supervisory framework}

Bank supervisors should promote soundness and stability of the financial system at all times during a pandemic. Bank supervisors will need to employ the flexibility embedded in the bank supervisory framework while striving to maintain internationally agreed minimum regulatory standards and supervisory principles. Unlike developed countries, bank supervisors in developing countries have fewer policy options at their disposal, and may lower their prudential standards below the internationally agreed minimum regulatory standards due to limited policy buffers, weaker implementation capacity, and less-sophisticated regulatory frameworks (Adrian and Pazarbasioglu, 2020). The problem with lowering prudential ratios below the minimum standards is that such policy move or action could sow the seeds of destruction that may destabilize the financial system in the future or in the long term.

\subsection{Modify bank supervisory examinations}

Bank supervisory examinations will change during a pandemic. Bank supervisors should ensure that how bank supervisory examinations are conducted during a pandemic differs from their pre-pandemic routine. For example, bank supervisory examinations may be conducted off-site. Also, a streamlined approach can be used for the examination of low-risk banks and moderate-risk banks so that more supervisory resources can be focused on the examination of high-risk banks.

Regardless of the riskiness of each bank, bank supervisory staff should continue to monitor the safety and soundness of all banks. More importantly, bank supervisors should communicate to banks in clear terms that banks will not be penalized for dealing with their borrowers who are having financial 
difficulties associated with the pandemic. Such communication between bank supervisors and bank management is vital to help supervisors understand the unique challenges that each bank is facing during the pandemic as well as the long-term effects the pandemic will have on all banks.

\subsection{Use Ad Hoc stress tests}

Bank supervisors should adjust their routine stress test process during a pandemic. Supervisors should perform non-routine ad hoc exercises to assess the vulnerability of the banking sector to the pandemic. The ad hoc exercises will be different from the regular stress tests in terms of the objectives, design, scenarios, methodologies and communication (Baudino, 2020). Such ad hoc stress tests should support the assessment of the impact of the pandemic on the entire banking sector. Also, an ad hoc approach to stress test can allow the authorities to further adjust their stress tests from time to time as the pandemic evolves from low severity to high severity. Furthermore, an ad hoc approach to stress tests during a pandemic can help authorities to achieve the necessary balance between keeping banks safe, and ensuring an adequate flow of credit to the real economy (Baudino, 2020).

\subsection{Release the countercyclical capital buffer to banks}

Another measure to support banks in providing credit to the economy is to temporarily release the countercyclical capital buffer to banks. Bank supervisors can do this by reducing the countercyclical capital buffer rate from say $2.5 \%$ to $0 \%$ of banks' exposures to borrowers during a pandemic. The released countercyclical capital buffer can provide sufficient liquidity to banks which can then be extended as loans to meet the needs of businesses and households during the temporary disruption caused by a pandemic. The countercyclical capital buffer can then be increased after the disruption caused by the pandemic is over. 


\subsection{Increased use of regulatory forbearance}

Bank supervisors can use regulatory forbearance as a tool to reduce the regulatory burden on regulated financial institutions especially banks during a pandemic. Regulatory forbearance occurs when regulators give some banks, or all banks, an extended period of time during which they have to comply with specific regulatory requirements. It reflects the unwillingness of regulators to take disciplinary action against banks that fail to comply with certain regulations over a period of time.

Regulatory forbearance may take the form of freezing the classification status of some or all credit exposures prior to the pandemic; extending the number of days past-due after which a loan is considered to be nonperforming; allowing banks to postpone adequate provisioning which permits underprovisioning during a pandemic; or completely suspending the provisioning requirements for loans covered by moratoria. These measures offer shortterm relief to banks during a pandemic, even though these measures also undermine sound credit risk management in banks and may expose the banking system to significant credit risk in the long term (IMF-World Bank, 2020.

\section{Conclusion}

This article highlighted and discussed some approach to financial regulation and bank supervision during a pandemic. The author offered some financial regulation suggestions for coping with the negative effect of a pandemic on the financial sector such as the need to diversify the financial system; maintain adequate liquidity in the financial system; stimulate financial institutions to provide more credit; delay the recognition of significant increase in credit risk; lower the reference interest rate to encourage more lending; and providing 
stimulus packages to the general economy. Also, some suggested measures of bank supervision during a pandemic were provided. They include: adopting a flexible supervisory framework, modifying bank supervisory examinations, using ad-hoc stress tests, releasing the countercyclical capital buffer to banks, and increased the use of regulatory forbearance.

The implication of these approach to coping with a pandemic is that these measures can help to ensure the survival of small and large businesses and financial institutions. It can also help to preserve jobs and help to reduce the long term damage to the economy caused by the pandemic.

One limitation of using these approach to cope with a pandemic in all countries is that it may be difficult to adopt in all countries due to country-specific differences in bank supervisory capacity, financial regulatory standards, few financial resources, structure of the banking system and the level of financial development.

Future studies can examine whether the financial regulatory tools used to survive the 2008 global financial crisis are also effective in mitigating the negative effect of a pandemic on the banking sector. Future studies can also identify other monetary policy tools that are effective in dealing with a crisis other than those mentioned in this paper. 


\section{Reference}

Adrian, T. and Pazarbasioglu, C. (2020). Combating COVID-19: How should banking supervisors respond? World Bank Blogs. JUNE 15. Available: https://blogs.worldbank.org/voices/combating-covid-19-how-shouldbanking-supervisors-respond

Ari, A., Chen, S., \& Ratnovski, L. (2020). COVID-19 and non-performing loans: lessons from past crises. Available at SSRN 3632272.

Baudino, P. (2020). Stress-testing banks during the Covid-19 pandemic. Financial Stability Institute (FSI) Briefs, No 11, pp. 1-7. 12 October 2020. Available: https://www.bis.org/fsi/fsibriefs11.pdf

Chudik, A., Mohaddes, K., Pesaran, M. H., Raissi, M., \& Rebucci, A. (2020). A counterfactual economic analysis of Covid-19 using a threshold augmented multi-country model (No. w27855). National Bureau of Economic Research.

Demirguc-Kunt, A., Pedraza, A., \& Ruiz-Ortega, C. (2020). Banking sector performance during the covid-19 crisis.

Didier, T., Huneeus, F., Larrain, M., \& Schmukler, S. L. (2020). Financing Firms in Hibernation during the COVID-19 Pandemic.

Fan, E. X. (2003). SARS: Economic Impacts and Implications. Asian Development Bank ERD Policy Brief Series, NO. 15. May, Philippines.

Giese, J., \& Haldane, A. (2020). COVID-19 and the financial system: a tale of two crises. Oxford Review of Economic Policy, 36(Supplement_1), S200-S214.

Goodhart, C. and Wagner, W. (2012). Regulators should encourage more diversity in the financial system. VOX EU CEPR, 12 April 2012. Media Report. Available at: https://voxeu.org/article/regulators-should-encourage-morediversity-financial- 
system?keepThis $=$ true $\& T B$ iframe $=$ true $\&$ height $=650 \&$ width $=850 \&$ caption $=e$ urope

IMF-World Bank (2020). COVID-19: The Regulatory and Supervisory Implications for the Banking Sector. A Joint IMF-World Bank Staff Position Note. May 21.

Jing, E. (2020). Impact of high non-performing loan ratios on bank lending trends and profitability. Available at SSRN 3670002.

König, M., \& Winkler, A. (2020). COVID-19 and Economic Growth: Does Good Government Performance Pay Off? Intereconomics, 55(4), 224-231.

Li, L., Strahan, P. E., \& Zhang, S. (2020). Banks as lenders of first resort: Evidence from the COVID-19 crisis. The Review of Corporate Finance Studies, $9(3), 472-500$.

Meagher, P. (2020). Microfinance in the COVID-19 Crisis: A Framework for Regulatory Responses. Insights for Inclusive Finance. CGAP, June.

Ozili, P. K., \& Arun, T. (2020). Spillover of COVID-19: impact on the Global Economy. Available at SSRN 3562570.

Ozili, P. (2020a), "COVID-19 in Africa: socio-economic impact, policy response and opportunities", International Journal of Sociology and Social Policy

Ozili, P.K. (2020b). COVID-19 pandemic and economic crisis: the Nigerian experience and structural causes. Journal of Economic and Administrative Sciences.

Schularick, M., Steffen, S., \& Tröger, T. H. (2020). Bank capital and the European recovery from the COVID-19 crisis.

Topcu, M., \& Gulal, O. S. (2020). The impact of COVID-19 on emerging stock markets. Finance Research Letters, 36, 101691. 
World Economic Forum (2020). Impact of COVID-19 on the Global Financial System: Recommendations for Policy-Makers Based on Industry Practitioner Perspectives. April.

Zhang, D., Hu, M., \& Ji, Q. (2020). Financial markets under the global pandemic of COVID-19. Finance Research Letters, 101528. 